$$
\begin{array}{cccc}
\text { S sciendo } & \text { International Conference KNOWLEDGE-BASED ORGANIZATION } \\
\text { Vol. XXV } & \text { No } 1 & 2019
\end{array}
$$

\title{
IRREGULAR WARFARE. UNDERSTANDING THE ROLE OF PEOPLE
}

\author{
Laviniu BOJOR
}

\author{
“Nicolae Bălcescu”, Land Forces Academy Sibiu, Romania \\ laviniu.bojor@gmail.com
}

\begin{abstract}
The time of conventional conflicts and warfare between states or regular armies has come to an end. The recent theatres of operations have shown us that the Irregular Warfare, marked by the concealment of combatants among the civilian population, has captured the way of conducting military actions. The paper identifies the role of local communities in conflict zones, and their influence in the outcome of armed confrontations.
\end{abstract}

Keywords: irregular warfare, population, roles, center of gravity

\section{Introduction}

Crises and armed conflicts continue to be present in a world that promotes the climbing of the individual from the wild and barbarian stages to those marked by culture and high civilization. Access to the specific informational era of the $21 \mathrm{st}$ century did not, unfortunately, lead to the disappearance of crises and armed confrontations. We are still witnessing major arming and military preparations to overcome a more or less symmetrical opponent. This paper aims to answer the question of the role of the local population in the recent armed conflicts by analyzing how it interacts with the parties involved and how much it can influence the final outcome or the physiognomy of military actions.

\section{Irregular warfare: old concept - new concern}

Nation-state actors continue to create global insecurity through sustained territorial aggression policies (e.g. annexation of the Crimean peninsula to Russia), along with the political-military aspirations of some paramilitary terrorist groups (e.g. ISIS actions in the Middle East and North Africa). Battlespaces continue to bring face to face high-tech nation-state or powerful coalition states, usually conventionally organized type (hereafter referred to as "strong side") against poor, underdeveloped but strongly motivated non-state actors (hereafter referred to as "weak side").The characteristics of the most recent theaters of operations (Vietnam, Somalia, Afghanistan, Iraq, Lebanon, Gaza) have highlighted that military superiority is not enough to achieve a clear victory, and the prevalence of irregularity, marked by hiding combatants among the local population, diminishes the technological superiority of the "strong side".

\section{O-RMA - Other Revolution on Military Affairs}

The investment in R\&D (research and development) of the state actors has made the innovations (not revolution) of military affairs be taken over and used to achieve military superiority on the battlespace. Air Land Battle (ALB), Effects-Based Operations (EBO) or Network Centric Warfare $(\mathrm{NCW})$ are some of the concepts 
used by the powerful states to create an overwhelming force in order to apply the old Lightning War principle: "Shock and Awe". This trend was confirmed by certain events and armed confrontations (e.g. Falklands War, Gulf War). This trend has been confirmed by some conventional armed confrontations, which should not have led to unanimous assumptions about conflict physiognomy. While the great powers were occupied with their own plans, "on the other side of the hill", small actors, materialized by poor nations or non-state organizations, tried to deny or even eliminate military superiority through Other-RMA (Revolution in Military Affairs) [1]. For "weak sides" like Hamas or Hezbollah non-state groups, the change in military thinking has come from experiences that have forced them to adapt if they want to survive confrontations with the technological superiority of the state of Israel, backed by American state. Simultaneously with hiding the identity of combatants behind civilian clothing, the "weak side" identified indirect strategies for exploiting vulnerabilities. The first step was to reduce air support and limit the fire power by attracting battles into the narrow space of cities or in the impracticable slums areas of cities. At the same time, techniques, tactics and procedures have been identified and implemented to avoid or limit the loss in human lives. Most of them relied on the choice of target, place and moment of attack, learned by studying the lessons from previous guerrilla wars. But they were not limited to these. The widespread effects and the "low" cost of suicide attacks put terrorism first amongst societies where radicalization allows for mass manipulation and recruitment of "martyrs" willing to sacrifice for killing infidels. When regular forces extensively outnumber insurgents or the terrain is not favourable for guerrilla warfare, the only tactic that remains is terrorism [2]. Neither these actions are "recent" or "innovative", the suicide attacks of the Japanese kamikaze pilots generated the same feelings of fear and terror among US WW2 soldiers. Open field, direct and army versus army confrantations, specific to conventional conflicts have been replaced by conducting these types of indirect strategies. The concept of indirect strategy is built on two maneuvers, the interior and the exterior [3]. Interior directions are performed inside the AO (Area of operations) and depend on 3 factors: material force, moral force, and time. Depending on the capacities generated by the material and moral force, they engage in local instigation and attacks, forcing the strong side to allocate important resources to succeed in the overall control of large territories. Time is the advantage of the ,weak side" who decides to prolong the war and makes it too expensive for the strong side (financially, but especially in terms of human casualties). Specific thinking O-RMA promotes a long and costly war for the opponents, and vulnerabilities identified by the weak are exploited using "small bites" applied at the right place and time. Inherent mistakes and abuses of the "strong side" are exposed at once by the external direction, using the ubiquity of media technologies (smartphones, digital camera, pocket recorders etc) and the social platform of the global internet. This external direction seeks to obtain the support of the international community, recruitment of sympathizers, obtaining the necessary funds and equipment, while denying the opponent of international public support. It can easily be noticed that this indirect strategy follows in the same way the old advice of Mao Tse Tung's or Ghe Guevara, who encouraged the limitation of communist groups to conductopen actions until they succeed in attracting popular support and become strong enough to engage in direct attacks against government forces. 


\section{The Roles of Population}

Human walls protection against tank shots or ballistic missiles is the first factor that has guided weaker forces to hide inside local communities. Live images captured from drones, satellites, or other SIGINT / GEOINT equipment, the heat, thermal or infrared sensors of the "strong side", limit the "weak side" chance to hide inside the wooded, mountainous or other open space areas. The only remaining places to hide are human settlements.Human shields made up of women and children not only offer protection, but make it impossible to distinguish a terrorist from a civilian, and this confirms that the population has left the neutrality zone that is specific to conventional conflicts. Cover, concealment and force protection of the "weak side" against the high tech and fire power of the "strong side" is the main aspect that reveals the importance of the local population in the recent military conflicts.And force protection is not the only feature of local communities in favor of the weak side. They provide access to resources, the first being the human resource. The recruitment of combatants is done within the population, through coercion or volunteering. The growth of the young generation within a society based on hatred and violence (e.g. Palestinians in the Gaza Strip) allows terrorist groups to easily manipulate minors [4]. Radicalization of minors and young people becomes a natural process and fueling violence through followers ready to become martyrs, although they should not be accepted among combat groups because they have not reached the maturity necessary to understand the ideology accurately and have not developed their own system of values [5]. Radicalization of youth is not limited to recruiting those locally, the internet and social platforms sometimes succeeding in striking teenagers at a distance from the conflict zone. The West faces the extremist-terrorist radicalization of some native young people who had no previous connection with such ideologies or religions [6]. The recruitment of human resources is not limited to increasing the number of combatants. Children, women and old people are used as human sensors, warning or tracking routes or targets. Local residents are used for routine tasks such as message forwarding (couriers), medical personnel (doctors), procurement and transport of materials or weapons (logistic support). The personnel specialized in various fields (technical, economic, construction, chemical, communications, IT, telecommunication) is recruited and advanced to higher hierarchical levels based on know how. The financial resource is obtained by the "weak side" through the donations or the work of the local members or by the growth of an illegal economy (e.g. Afghanistan narco economy). Acces to moneyis also a factor that underlines the importance of local population in recent military conflicts. Last but not least, all conflicts, regardless of the nature, purpose or forces involved, are based on the information resource. Intelligence cannot be complete without HUMINT. Powerful GEOINT or IMINT is an incontestable advantage but is incomplete. Understanding the operational environment can only be achieved through access to real information from all areas that can influence the conduct of combat (political, military, economic, social) as perceived by the local population rather than by the actors involved. These aspects confirm the predominantly irregular characteristics of the recent military conflicts and active role played by the local population has in the relationship between the actors involved. 


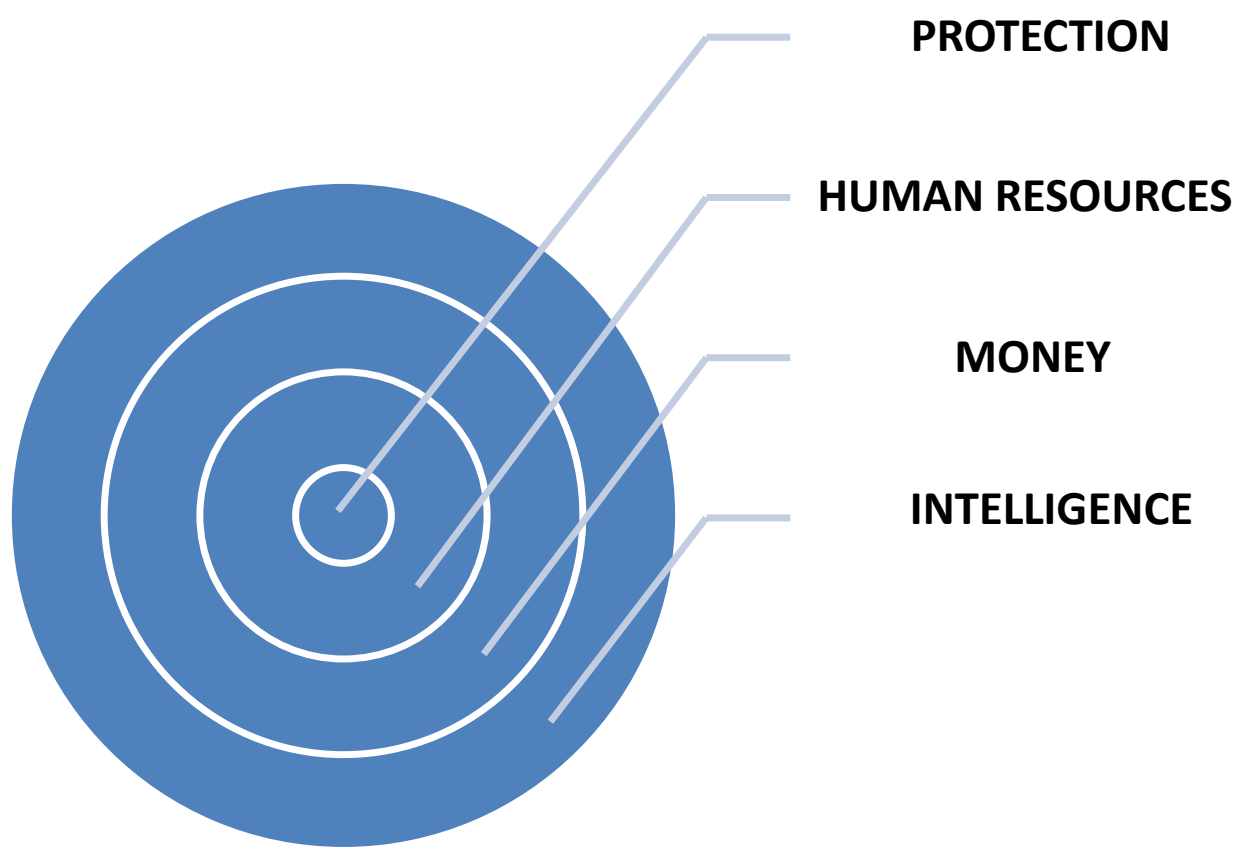

Figure no. 1: local population support

Benefits gained through local population support make them the center of gravity of armed confrontation (see fig. No. 1). Military superiority is important, but the main effort of the "strong side" must focus on attracting the local community alongside government forces. Remaining anchored in the outdated concept of conventional warfare: seeking and destroying the enemy or conquering the terrain, will result in a long-lasting conflict in which the "weak side" will have the initiative. Witha blurring line between civilians and opponents, continuing pressure to achieve tangible results and specific warfares violence, "strong side" will make a lot of mistakes and abuses. Civilian casualties will definitely lead to the loss of population support.

\section{Conclusions}

Getting people to support from the area of responsibility is the center of gravity of military actionconducted in conflicts marked by irregularity. Achieving this goal allows for the accomplishment of the main mission. It can only be obtained by placing the population first, stopping violence, achieving peace and restoring the social services affected by the conflict. The objectives of the missions in the area of responsibility should focus on protecting the population and effective collaboration that ultimately leads to legitimacy and popular support. It is the only way to avoid the opponent's access behind the human shiedstocommunity resources that fuel his power to fight.

\section{References}

[1] Brigadier General Itai Brun (2010) 'While You're Busy Making Other Plans' - The 'Other RMA', Journal of Strategic Studies, DOI: 10.1080/01402390.2010.489708, pp. 535-565.

[2] Andrea Beccaro (2018) Modern Irregular Warfare: The ISIS Case Study, Small Wars \& Insurgencies, DOI: 10.1080/09592318.2018.1433469, pp. 207-228. 
[3] Eriksson, G; Pettersson, U, (2017), Special Operations From A Small State Perspective: Future Security Challenges, Book Series: New Security Challenges, DOI: 10.1007/9783-319-43961-7 9, p. 143.

[4] Massimiliano Calì, Sami H. Miaari, 2015, Do Israeli settlements radicalize Palestinians?, accesed on site

https://www.google.com/url? sa $=t \& r c t=j \& q=\& e s r c=$ s\&source $=$ web\&cd $=2 \& v e d=2$ ahUKE wiEgeSxsILiAhWUwcQBHYC3CysQFjABegQIABAC\&url=http $\% 3 \mathrm{~A} \% 2 \mathrm{~F} \% 2 \mathrm{Fsiteresou}$ rces.worldbank.org\%2FINTMENA\%2FResources\%2FReport.pdf\&usg=AOvVaw3YEM 9aZXYaVbLeU03txS6O

[5] James Miller, Saira Shah, documentary Death in Gaza (2004).

[6] \#Millennialradical. Radicalizarea adolescenţilor, 11 february 2019, accesedon site https://intelligence.sri.ro/millennialradical-radicalizarea-adolescentilor/ 